\title{
Understanding Social Learning Behaviors via a Virtual Field Trip
}

\author{
http://dx.doi.org/10.3991/ijet.v9i4.1205 \\ Xin Bai ${ }^{1}$ and Joanne Lavin ${ }^{2}$ \\ ${ }^{1}$ York College of the City University of New York, USA \\ ${ }^{2}$ School of Professional Studies of the City University of New York, USA
}

\begin{abstract}
This is a multidisciplinary study investigating how a virtual rather than face-to-face field trip can be conducted in a real-world setting and how students respond to such a social learning opportunity. Our participants followed a story of a stroke patient at her virtual home and in a virtual hospital via a teaching vignette. They were then given a new case and got on a virtual trip via a multiuser virtual environment. They played the roles of patients, relatives, doctors, or nurses, experiencing the emotional, physical, or social impacts those stakeholders may go through. Our study finds the overall participation of the Virtual Group is $\mathbf{5 0 \%}$ more than the Text Group. Although the Virtual Group generates much more nodes in total, they focused much less on knowledge sharing and comparing than the Text Group (46 vs. 67), but more on other higher-level aspects of social interactions, such as knowledge discovery (57 vs. 42), co-construction (66 vs. 39), testing and modification (58 vs. 24) and application of newly constructed meaning (60 vs. 16). Analysis of students' virtual field activities and in-depth discussions of important issues implied are included to help understand social learning behaviors during a virtual field trip. Sustainability of such systems is discussed.
\end{abstract}

Index Terms-Simulations; Social Cognition, Educational Technology, Role-playing

\section{INTRODUCTION}

Learning without experiencing what is being learned is not meaningful [1]. Students need to be engaged actively with explanatory ideas and evidence that they can connect to real purposes and practices in their everyday worlds [2]. In recent years, virtual learning environments have been explored and evaluated by researchers and educators to determine whether they can serve as a more effective learning platform than a traditional text-based learning approach [3][4][5]. Classroom teachers are encouraged to demonstrate how using virtual rather than face-to-face professional training can be applied in a real-world setting [6]. Such development is due to not only the advances and affordance of technologies, but continued recognition that embodied cognitive experiences and multimodal representation of knowledge and skills enhance learning [7][8]. To build a mental perceptual simulation of what is being learned, a rich a perceptual experience as much as possible is required during learning [9].

In a traditional classroom, it is usually not practical or possible to situate students in a real life setting due to the constraints of costs, space, or risks. It is a common practice for instructors to conduct case studies via verbal description of real life situations. As the focus is mainly on content knowledge such as key concepts and procedures, students do not usually feel engaged and could easily feel overwhelmed by the facts and rules they need to memorize. Another limitation of such an approach is that it cannot adequately represent all the modalities of a real life situation. For instance, watching how a CT Scan machine works is much more effective than reading a manual. Additionally, hearing a "person" describe their symptoms is different than reading about them. It includes the nuances of tone that are not necessarily gleaned from written words. Also, a verbal description of such scenarios often fails to demonstrate affective knowledge such as emotions, facial expressions, or gestures. More research is needed to harness the advances of technologies in order to provide our students with a meaningful learning context similar to real life. MUVE is found to help teachers transcend to the expected face-to-face training for a more realistic transformative setting [10].

This study investigates the feasibility of providing virtual field trips to students who do not otherwise have a chance to practice in a real life setting. It examines students' engagement and assesses learning outcomes to determine the effectiveness of learning via a virtual field trip. The following questions guide this research: 1) How do students respond to and learn in virtual trips? 2) Do learners acquire such knowledge and skills differently?

\section{BACKGROUND}

\section{A. Serious Games}

Serious games refer to simulations of real-world events or processes designed for the purpose of educating, training, informing, or persuading intended users in education, military, business, or other industries. According to Abt [11], “.... [serious] games have an explicit and carefully thought-out educational purpose and are not intended to be played primarily for amusement." For instance, Darfur is Dying is an online game that simulates life in a Darfur refugee camp (http://www.darfurisdying.com/). FloodSim is a flood prevention simulation/strategy game designed to inform people about the danger of flooding (http://playgen.com/play/floodsim/). Peacemaker simulates Israeli-Palestinian conflict designed to promote "dialogue and understanding among Israelis, Palestinians and interested people around the world" (http://www.peacemakergame.com/). IBM developed CityOne, in which users experience some of the complex problems facing cities to understand business concepts and how to use technology to revolutionize industries (http://www-

01.ibm.com/software/solutions/soa/innov8/cityone/). 
Through such explorations, researchers found educational games help promote critical skills such as complex problem solving [12][13][14][15], failure and persistence [16][13], multitasking [12][13], pattern recognition [13], collaboration [12][16][13][17][18]; Leadership [19][20. Serious games can thus serve as an ideal learning platform for conducting virtual field trips where students can interact with domain experts and other stakeholders in a simulated professional context.

\section{B. Virtual Field trips}

Virtual field trips provide an alternative learning tool for involving students in the exploration of the real world when no actual field trips are possible for logistical, cost, time, and safety reasons. Students can take on a virtual trip via computers to a digital virtual environment that simulates a real world context. Embodied as stakeholders such as nurses, social workers, or patients, students can interact with the environment as well as other virtual professionals during a virtual trip. For instance, nursing students can role-play in a virtual hospital and student teachers can role-play in a virtual classroom. But the clinical experience of a physical field trip is usually not available to students until their senior year.

Studies show that both real and virtual field trips promote learning. A comparison of physical versus virtual field trips to the Indian River Lagoon demonstrates no significant differences in achievement, attitudes, learning styles, interactions between field trip and learning styles, or students' ability to answer questions at different levels [21]. A study comparing a real field trip and a virtual field trip indicates minute differences between the levels of knowledge acquisition effectiveness in the field of biology and ecology [22]. Today's instructors are encouraged to demonstrate how using virtual rather than face-to-face professional training can be applied in a real-world setting [23]. These results are encouraging for the adoption of virtual field trips as it's more feasible for educators to arrange a field trip anytime anywhere via computers over the Internet.

\section{Simulation-based Learning}

Simulation-based training, as a kind of serious games, is a method of education that is ideal for addressing cognitive and technical skills as well as behavioral skills. Classroom and campus lab simulations have been found to be an effective instructional strategy that can enhance graduates' transition from classroom to real-life practice, provide opportunities for students to analyze information, make clinical judgments, and respond as if working with actual patients [24]. Paige and Daley [25] suggest that simulation learning be viewed in a situated cognitive lens as a social activity incorporating the mind, the body, the activity, and the tools in a context that is complex and interactive. Educators believe that it is not until a student applies theory to a given problematic situation that true understanding materializes. Many organizations recommend the use of simulation especially for team building [25].

There is also an increasing body of evidence demonstrating self-efficacy of simulation use, most notably, an improvement in self-confidence among students. Many articles in the nursing literature identify the benefits of using various types of simulation to enhance selfconfidence as well as skill performance [26][27].
Simulation has not been restricted to nursing education. It was originally used in airplane pilot training and has been readily adopted by medical education programs, especially surgical training. Oishi et al [28] and Malone et al [29] reported on the benefits of using simulation in physician education training programs. Low et al [30], Walker et al [31] also provide support for the incorporation of simulated learning for training doctors. Kallonis \& Sampson [32] described their development of a 3D virtual classroom for teacher professional continuing education. Leung et al [33] investigated the effects of virtual industrial training on mental workload during task performance for employees in the manufacturing and service industries.

Still, the impact of simulation on the cognitive aspects of learning is not well understood and remains an important focus for future research. We previously adopted a multidisciplinary collaborative approach to develop a prototype of a virtual learning environment through a $3 \mathrm{D}$ virtual platform, Second Life [34][35]. Two case studies were piloted with a group of nursing, physician assistant and occupational therapy students to determine student engagement and learning attitudes. The results have led to this study, which focuses on what happened during a field trip and how students respond to such experiences.

\section{METHOD}

\section{A. Design-based Research Methodology for the Development of the Virtual Environment}

The design for this investigation is a design based research focusing on the unique learning opportunities afforded by $3 \mathrm{D}$ teaching vignettes. It involves the analysis of the use and performance of designed artifacts to understand, explain and very frequently to improve on the behavior of aspects of Information Systems [36]. Introduced by Brown [37], design research was developed as a way to carry out formative research to test and refine educational designs based on principles derived from prior research [38]. This involves reiteration of certain project design phases, which allows us to quickly identify potential problems and solve them in a timely manner to avoid disastrous system failure in the future.

We evaluated Second Life, OpenSim, SimCity, Flash, Director, and Unreal. Then we narrowed down to a MUVE, Second Life, as it provides virtual reality contexts that support social interaction such as role-playing. Second Life does not embed explicit game rules or gamebased rewards like those in commercial multi-player online games. But it supports for constructivist learning by allowing for meaningful knowledge construction from a first-person perspective in a social setting [39][13][40]. Second Life is a user-friendly 3D simulation platform. Little or no prior gaming experience is needed for users to learn how to navigate and interact with others. Users can create buildings, roads, bridges as well as other artifacts such as vehicles, trees, animals, or even zombies. The basic unit of these virtual items is a primitive, or prim, which is represented by a set of parameters including shape, position, size, rotation, hollow, twist, etc. There is a built-in authoring tool that allows users to construct 3D objects made out of prims and design behaviors via scripts. Second life was therefore adopted as the researchers' platform for developing $3 \mathrm{D}$ teaching vignettes.

We purchased virtual land and assembled buildings made out of prim objects. A basic clinic was set up that 
includes a front desk with a waiting area, an observation room with equipment such a heart monitor, ultrasound machine, a CT scanner, a sink to wash hands, cabinets with medical instruments, and hospital beds with curtains (Figure 1).

Researchers in Nursing first wrote a case study script on the topic of Strokes (CVA) and designed assessment instruments. The plan was to play out this scenario and videotape it as a 3D teaching vignette to be used in basic baccalaureate nursing curriculum as well as in acute care hospital settings for Registered Nurse (RN) continuing education. The case is about an older woman who develops a stroke and follows her emergency admission through discharge. The woman has many of the risk factors for strokes: she did not consistently take her medications nor follow the recommended diet. The story guides students through the assessment and acute management of a stroke. Constant communication among the researchers and domain experts are established to achieve a better understanding of domain specific contents such as NIHH/Glasgow Scales or t-PA. The NIH stroke scale (NIHSS) measures several aspects of brain function, including consciousness, vision, sensation, movement, speech, and language. A certain number of points are given for each impairment uncovered during a focused neurological examination. For instance, in the exam the patient is asked to open/close eyes, lift a leg, open/close mouth, squeeze hand, read words/sentences or describe a picture (Figure 2).

Next, a 3D teaching vignette was developed in Second Life. Machinima was adopted as a technique that uses real-time 3D computer graphics rendering engines to create a movie. Camtasia was used as a screen-casting tool to record the story played out in Second Life. Animated PowerPoint slides were added to illustrate family trees or dosage calculation. Scripts were attached to some of virtual objects that functioned as action triggers. For instance, touching a question or picture on the NIHSS poster will allow nurses to hear a patient's response to that question or picture. Some customized actions, such as facial droop or sweating, were saved to a pre-designed action library so that users can choose to execute them from a dropdown list. However, users need training to learn how to execute these actions. There is currently no intuitive way to execute these actions.

\section{B. Participants and Procedures}

Twenty undergraduate students participated in the study on April 10, 2013. They were recruited from the department of Nursing Education at an urban public university. They were randomly allocated for a field trip: one group role-played via text chatting online; the other group conducted role-playing in a simulated virtual environment (Table I).

The participants were first informed about the purpose, learning outcomes, and format of the study before they were given written consent forms. An instructor gave a lecture on the topic of CVA. The students went through a case study on a stroke patient. Then each student received an index card giving simple descriptions of the roles that they will play. These roles include: patients, relatives, nurses, and doctors.
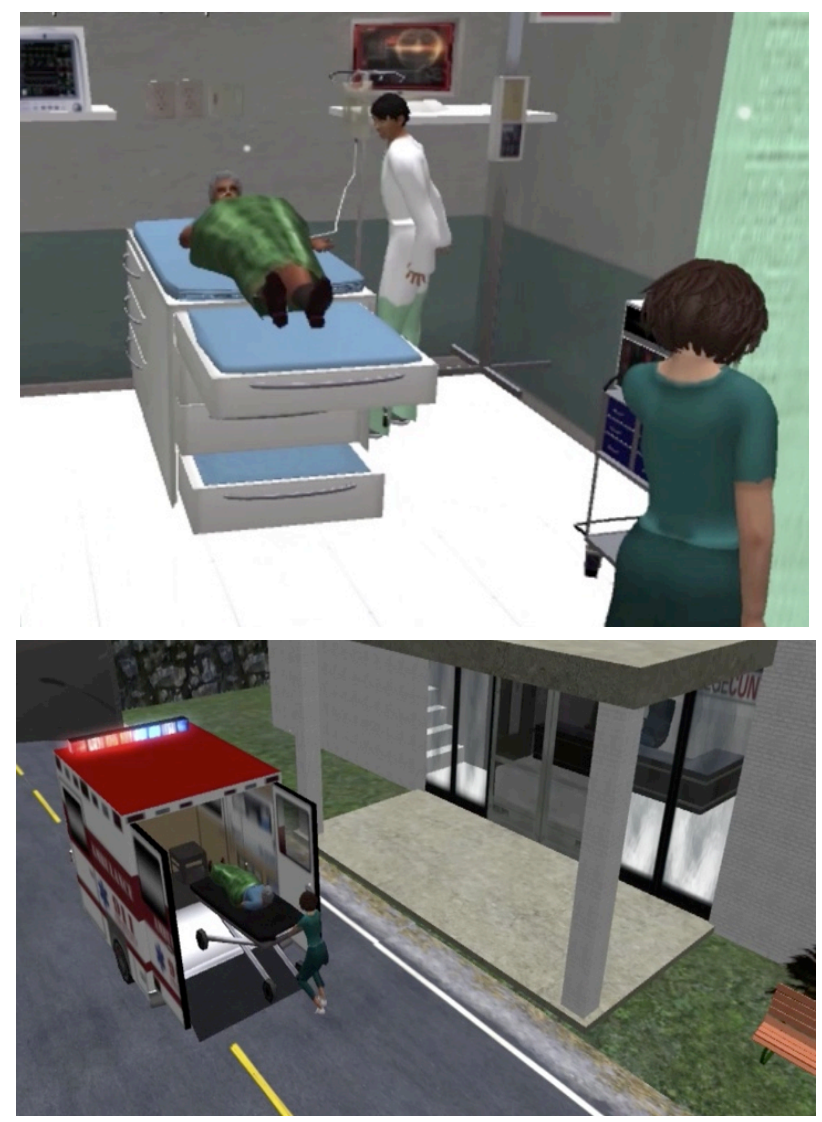

Figure 1. A virtual hospital with equipment
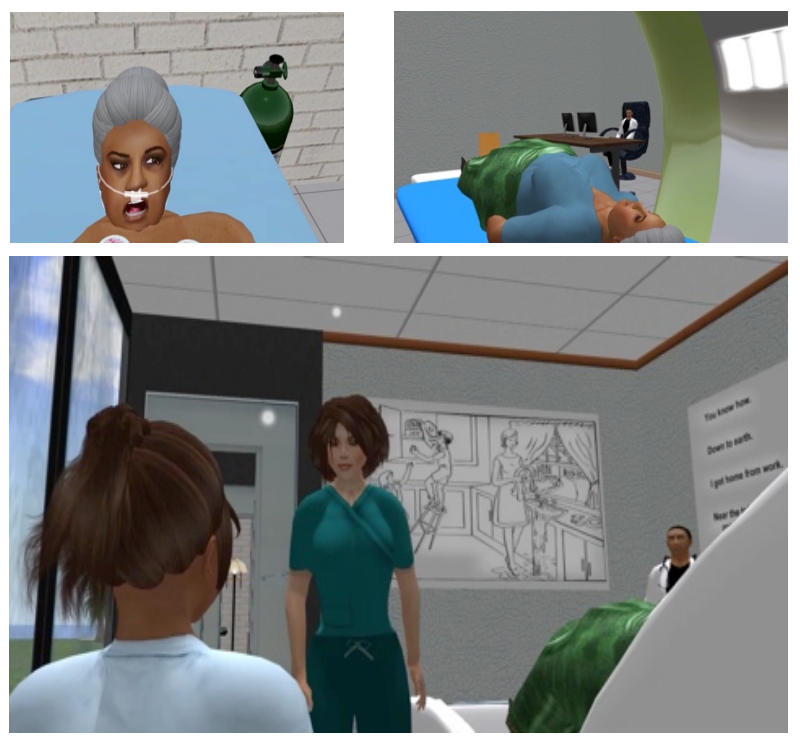

Figure 2. Avatar behaviors (from left to right: open mouth; go through CT Scanning, take NIHSS exam)

TABLE I. STUdy DESIGN (N=20)

\begin{tabular}{|c|c|c|c|c|c|}
\hline Groups/Steps & Pre-test & $\begin{array}{c}\text { Orienta- } \\
\text { tion }\end{array}$ & \begin{tabular}{|c|} 
Case \\
Study
\end{tabular} & Role-Play & Post-test \\
\hline Duration & (15 min.) & $(15 \mathrm{~min})$. & $(30 \mathrm{~min})$. & $(50 \mathrm{~min})$. & $(20 \mathrm{~min})$. \\
\hline $\begin{array}{l}\text { Text Group } \\
(10)\end{array}$ & & & & $\begin{array}{l}\text { Role-play via } \\
\text { text chatting }\end{array}$ & \\
\hline $\begin{array}{l}\text { Virtual Group } \\
(10)\end{array}$ & & & & $\begin{array}{l}\text { Role-play via } \\
\text { 3D simulations }\end{array}$ & \\
\hline
\end{tabular}




\section{Data Coding Scheme and Analysis}

We used Blackboard, a learning management tool for text-based role-play. Students logged on to their account and entered a chat room that an instructor set up. The conversations were saved as text logs. The conversations and behaviors in the virtual learning environment, Second Life, were recorded via a screen capture tool called Camtasia.

In this paper, the social aspect of the learning behavior was selected to provide an insight into the research questions. The social knowledge co-construction is analyzed via the coding scheme of the Interaction Analysis Model (IAM) [41] (Table II), which has been adopted by researchers to analyze learners' interactive social knowledge co-construction in online behaviors (e.g., [42][43][44] [45][46]). Each turn of student conversations was treated as one unit and classified into five themes within IAM. These themes are sharing, comparing of information; discovery of dissonance; negotiation of meaning/ coconstruction of knowledge; testing and modification of proposed synthesis; agreement or application of newly constructed meaning. We added the sixth theme, others, for irrelevant information. The researcher with professional backgrounds in psychology completed the coding.

\section{RESUlTS AND DISCUSSION}

Based upon the six coding themes mentioned above, the Text Group generated 195 nodes; while the Virtual Group generated 294 nodes (Figure 3). This indicates the Virtual Group participated much more than the Text Group during the virtual field trip, even though they had a steeper learning curve navigating in the new virtual environment, Second Life. The irrelevant information (S6: Others) is extremely low in both groups (7 vs. 7), suggesting both groups were engaged in role-playing productively throughout the field trips.

TABLE II.

GUNAWARDENA, LOWE \& ANDERSON'S INTERACTION ANALYSIS MODEL

\begin{tabular}{|l|l|}
\hline \multicolumn{1}{|c|}{ Phase } & \multicolumn{1}{|c|}{ Operation } \\
\hline $\begin{array}{l}\text { 1. Sharing / comparing of in- } \\
\text { formation }\end{array}$ & $\begin{array}{l}\text { Statement of observation or opinion; } \\
\text { statement of agreement between par- } \\
\text { ticipants }\end{array}$ \\
\hline $\begin{array}{l}\text { 2. Discovery and exploration of } \\
\text { dissonance or inconsistency } \\
\text { among participants }\end{array}$ & $\begin{array}{l}\text { Identifying areas of disagreement, } \\
\text { asking and answering questions to } \\
\text { clarify disagreement }\end{array}$ \\
\hline $\begin{array}{l}\text { 3. Negotiation of meaning/co- } \\
\text { construction of knowledge }\end{array}$ & $\begin{array}{l}\text { Negotiating meaning of terms and } \\
\text { negotiation of the relative weight to } \\
\text { be used for various agreement }\end{array}$ \\
\hline $\begin{array}{l}\text { 4. Testing and modification of } \\
\text { proposed synthesis or co- } \\
\text { construction }\end{array}$ & $\begin{array}{l}\text { Testing the proposed new knowledge } \\
\text { against existing cognitive schema, } \\
\text { personal experience or other sources }\end{array}$ \\
\hline $\begin{array}{l}\text { Agreement state- } \\
\text { ment(s)/application of newly } \\
\text { constructed meaning }\end{array}$ & $\begin{array}{l}\text { Summarizing agreement and meta- } \\
\text { cognitive statements that show new } \\
\text { knowledge construction }\end{array}$ \\
\hline
\end{tabular}

\section{Comparison of Interactions between the Text and Virtual Groups}

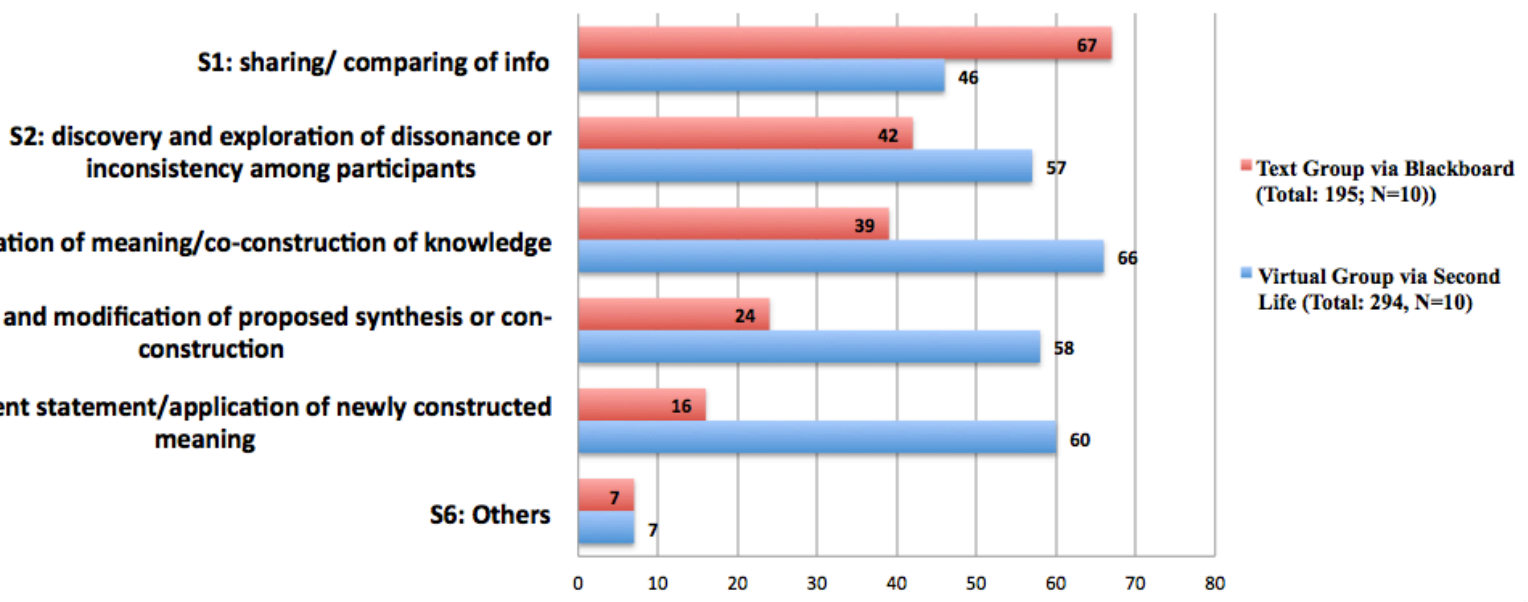

Figure 3. Comparison of social interactions between the Text $(\mathrm{N}=10)$ Group and Virtual Group ( $\mathrm{N}=10)$. Each turn of conversation is coded as one node.

The distribution of the nodes of social interaction for knowledge construction is shown in Figure 4. Although the Virtual Group generates much more nodes in total, they focused much less on S1 (sharing and comparing) than the Text Group (67 vs. 46), but more on other higher level aspects of social interactions. This suggests that Text Group explored less on knowledge co-construction with other stakeholders. The decreased number of nodes from S2 to S5 indicates that the Text Group were not able to build-on to each other's ideas. Instead, they ask questions or clarify ideas without further negotiation. The Virtual
Group consistently build knowledge in all the phases of social interactions.

A closer look at what's going on in both groups help identify what leads to such drastic different results. Figure 5 displays the percentage of social interactions within each group. The Text Group's participation was 34\% (S1), 22\% (S2), 20\% (S3), 12\% (S4), and 8\% (S5). The result is consistent with several studies based upon the IAM model [41][47][48], where much of the activities are around sharing information and clarifying basic questions. Those results seem to indicate that "higher phases of coconstruction of knowledge are difficult to achieve" [46]. 


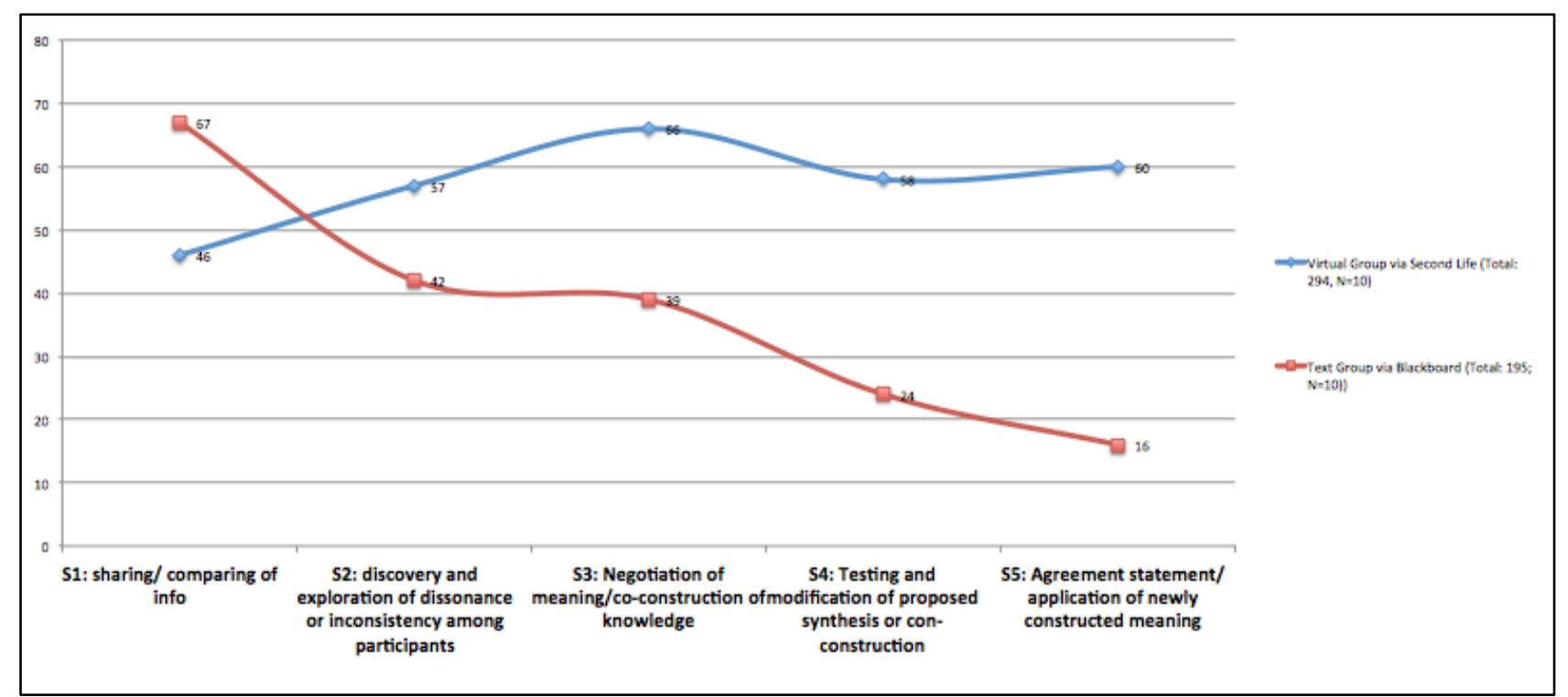

Figure 4. The distribution of the nodes of social interaction for knowledge construction.

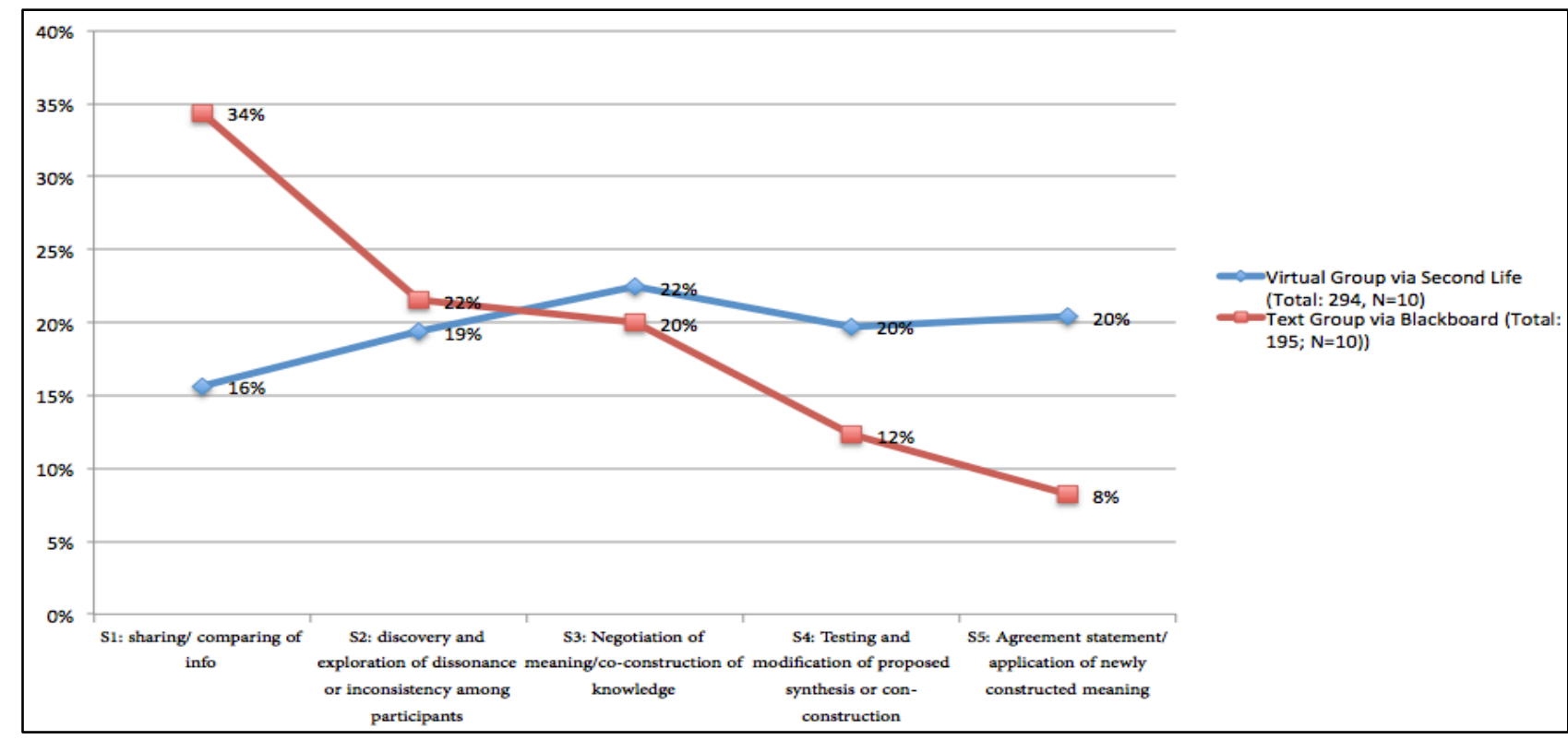

Figure 5. The distribution of nodes of social interaction for knowledge construction (\%).

However, the Virtual Group's result is more encouraging: the participation was $16 \%$ (S1), 19\% (S2), 22\% (S3), $20 \%$ (S4), and 20\% (S5). Also, the overall participation is $50 \%$ more than the Text Group. There are several possible reasons that could account for such results. First, students in a virtual environment were more immersed in the roles they were playing than a text-chatting group where participants can only imagine what they could see or do. They can represent themselves as avatars with specific age, ethnicity, or body shape. They received more communication clues: such as other avatars' facial expressions or gestures. For instance, in the role-play, a stroke patient, Samuel Deck, and his daughter, Rose Deck, were two characters that were supposed to have different temperaments and goals. Samuel was very sick and helpless. Rose was worried, impatient, and demanding. Playing out the roles allows nursing students to learn to empathize with the clients and understand the need for appropriate and efficient communications. From the scripts below, we captured the chaos: the patient suffered; the daughter tried to help; the nurse didn't respond the request, as he/she was busy or perhaps overwhelmed. In Figure 6, and Figure 7, we can see the Virtual Group was more emotionally involved. Their conversation was thus vivid and full of details. The father pressed for urgent issues to be fixed and the daughter tried all she could to help with the father. The Text Group's discussion was dry. The daughter seemed to a bit detached, asking random questions regarding her father.

Second, the virtual hospital gave the virtual group a tangible and meaningful real-life virtual context that enables the students to reduce the cognitive overload of simulating the virtual environment in their working memory while trying to conduct clinical reasoning during the field trip. Also, when they see the patient being examined in the CT Scan room, everybody else can see the same event. This allows for the role-playing events to carry out smoothly as people progress through the processes. In the Text Group, students have to create the virtual hospital 
Samuel Deck: $\quad$ I don't feel good. I don't know what is happening. I am tired

Rose Deck: Don't you think you should let my father rest?

Is my father going to die?

I am his daughter

We want a specialist, not some regular doctor

Samuel Deck: $\quad$ That's my daughter

I need to pee.

Rose Deck: I I want to know what's wrong with my dad.

Samuel Deck: $\quad$ Rose be quiet she is helping me.

Nurse! I need to pee now.

Rose Deck: $\quad$ My dad has to use the bathroom his bladder is about to explode.

What are you people doing?

Samuel Deck: $\quad$ Rose can you do something!

Rose Deck: $\quad$ Fine, I'll get the urinal for you dad because these people aren't helping you.

Samuel Deck: $\quad$ Hunny they are going to make me pee on myself.

Can you tell them to help me pee omg what does it take for me to pee.

I don't want nothing done on me I need to pee.

Rose Deck: $\quad$ Ok dad here is the urinal.

Samuel Deck: Thank u rose your finally helping.

Rose Deck: $\quad$ ur welcome dad

Can someone please tell me WHY my dad had a stroke???? PLEASE

Samuel Deck: $\quad$ Yes i need to know. nurse why did i have a stroke?

Rose Deck: $\quad$ I'm going to get my dad out of here you people are useless

Samuel Deck: $\quad$ Why cant u explain nurse!? You're the nurse

Samuel Deck: $\quad$ You should know

Samuel Deck: $\quad$ Susan I'm not dying

Rose Deck: $\quad$ How do you know dad you could be dying but this so called doctor doesn't know anything

Ok I know that and he also smokes is that bad too?

Samuel Deck: $\quad$ I am so confused.

Figure 6. Conversations between the patient, Samuel, and his daughter, Rose, in the virtual world.
Rose Deck:
Yes but no one is telling us anything, you've been running tests since we got here Is he going to be Ok?
Look everyone is sitting around doing a lot talking, what are you going to do for him?
Are you a stroke specialist Dr.?
So how are we supposed to help him if he has all these factors against him?
Samuel Deck:
So what's gonna happen to me now?
Samuel Deck:
Is the result of all the tests in yet? I wanna go home
Samuel Deck:
Am I gonna get any medication right now?
Rose Deck:
Samuel Deck:
Nurse, my father wants to know what you are going to give him right now?
I just pee what did you do with it nurse?
Rose Deck:
Shouldn't we let my father rest now?
Rose Deck:
Doctor what's happening to my father?

Figure 7. Conversations between the patient, Samuel, and his daughter, Rose, via text chatting.

and the characters in their mind while conversing with others. The conversations often lost focus as people may have been imagining different contexts and talking about different concerns. That could explain why the Text Group generated much less nodes from interaction levels from S2 to S5 as they had difficulty building on each other's ideas without visual contexts as clues.

Figure 8 shows the case scenario scripts that guided the Virtual and Text Groups during their field trip. In both groups, the patient and relatives participated actively based upon the guiding scripts. But the nurses in the Virtual Group carried out more procedures and engaged more with the patient and relatives. For instance, the nurses in the Virtual Group greeted the patient and relatives and explained in detail what happened, what would be measured, why, and what was next in a more systematic way. On the other hand, the nurses in the Text Group only gave brief explanation of what they were doing and they seemed to conduct assessment on the patients in a more random order. 


\begin{tabular}{|c|c|c|}
\hline $\begin{array}{l}\text { Case scenario scripts: } \\
\text { Actions/roles/ tasks }\end{array}$ & Virtual Group's Field Trip & Text Group's Field Trip \\
\hline $\begin{array}{l}\text { Patient arrives in ER. } \\
\text { The patient has difficulty articu- } \\
\text { lating answers to the questions } \\
\text { asked, speaking only a few } \\
\text { words and frequently respond- } \\
\text { ing with just a verb or a noun. } \\
\text { His ability to respond to com- } \\
\text { plicated verbal commands, } \\
\text { whether spoken or written, is } \\
\text { not impaired. } \\
\text { Upon examination by the emer- } \\
\text { gency room physician, Samuel } \\
\text { is found to have right hemipare- } \\
\text { sis and diminished pinprick and } \\
\text { two-point discrimination on the } \\
\text { right side of his head and arm. } \\
\text { Patient has an emergency CT } \\
\text { scan in the ER }\end{array}$ & $\begin{array}{l}\text { Nurse measures patient's blood pressure, heart rate. } \\
\text { "Hello my name is Natalie and I will be your nurse for today. } \\
\text { The ct scan is complete. I will bring you to your room." } \\
\text { Patient: I don't feel good. I don't know what is happening. I } \\
\text { am tired } \\
\text { Daughter: } \\
\text { Don't you think you should let my father rest } \\
\text { Is my father going to die? } \\
\text { I am his daughter } \\
\text { We want a specialist, not some regular doctor } \\
\text { I want to know what is wrong with my dad. }\end{array}$ & $\begin{array}{l}\text { Daughter: } \\
\text { Yes but no one is telling us anything, you've } \\
\text { been running tests since we got here } \\
\text { Is he going to be Ok? } \\
\text { Look everyone is sitting around doing a lot } \\
\text { talking, what are you going to do for him? } \\
\text { Where is the oxygen? } \\
\text { Patient } \\
\text { So what's gonna happen to me now? } \\
\text { Is the result of all the tests in yet? I wanna go } \\
\text { home }\end{array}$ \\
\hline $\begin{array}{l}\text { The patient is assessed } \\
\text { The patient becomes agitated } \\
\text { each time his daughter asks } \\
\text { questions. } \\
\text { His deep tendon reflexes are } \\
\text { brisk on the right and there is a } \\
\text { positive Babinski reflex on the } \\
\text { right; the blood sugar is } 98 \mathrm{~g} \text {; BP } \\
\text { is } 160 / 100 \mathrm{mmHg} \text {. }\end{array}$ & $\begin{array}{l}\text { Nurse \#1 } \\
\text { "You are in the hospital right now. I am going to do an as- } \\
\text { sessment on you including vital signs, blood sugar, and neu- } \\
\text { rological tests."- and assesses pupil reactivity; muscle } \\
\text { strength. Determines if there is any facial asymmetry. As- } \\
\text { sesses deep tendon reflexes; Assesses the patient's ability to } \\
\text { respond to verbal commands. } \\
\text { Nurse \# } 2 \text { I am your nurse, Nancy. Assesses the vital signs } \\
\text { and blood sugar. } \\
\text { "How severe is your headache? On a scale of } 0 \text { to ten with } \\
\text { ten being the worst pain you have felt- how would you rate } \\
\text { your pain?" } \\
\text { "Do you know where you are now? } \\
\text { "I am assessing his ability to swallow saliva" } \\
\text { The patient is not drooling. } \\
\text { The patient's voice quality is not wet or gurgled. } \\
\text { The Glasgow coma scale- } 13 \\
\text { The blood sugar is } 98 \text { mg/dl } \\
\text { Patient: } \\
\text { I need to pee. } \\
\text { I don't want nothing done on me } \\
\text { "Please don't let me die; stop this headache; I can't see." } \\
\text { I waughter: } \\
\text { My dad has to use the bathroom. } \\
\text { Wow so he had a clot in his brain, that sounds dangerous } \\
\text { Patient: } \\
\text { Rose be quiet she is helping me. } \\
\text { Nurse! I need to pee now. }\end{array}$ & $\begin{array}{l}\text { Nurse } \\
\text { "We are here to help you." And performs a } \\
\text { neuro assessment: Assesses level of conscious- } \\
\text { ness -"Do you know where you are?"- } \\
\text { Patient: } \\
\text { Am I gonna get any medication right now? } \\
\text { I'm going home } \\
\text { Okay } \\
\text { Daughter: } \\
\text { But dad you don't know where home is. } \\
\text { Are you a stroke specialist Dr.? } \\
\text { Nurse, my father wants to know what you are } \\
\text { going to give him right now? } \\
\text { Wife: }\end{array}$ \\
\hline $\begin{array}{l}\text { tPA medication is adminis- } \\
\text { tered for the stroke }\end{array}$ & $\begin{array}{l}\text { Nurse } \\
\text { "the medicine should help lower his blood pressure and the } \\
\text { IV to rehydrate him" } \\
\text { "I am going to give you } 500 \mathrm{ml} \text { of normal saline solution IV- } \\
\text { and adds IV fluids ( } 500 \mathrm{~mL} \text { Normal Saline); and re-assesses } \\
\text { the blood sugar and vital signs } \\
\text { "Your dad has weakness on the right side." } \\
\text { "This medicine helps break down the clot." } \\
\text { Daughter: } \\
\text { "I want to know what is going on with my dad." } \\
\text { "My dad has to use the bathroom his bladder is about to } \\
\text { explode." } \\
\text { "What are you people doing?" }\end{array}$ & $\begin{array}{l}\text { Nurse } \\
\text { Explains that he will receive tPA. } \\
\text { "The tPA will break down the clot that caused } \\
\text { the stroke." } \\
\text { Daughter: } \\
\text { Shouldn't we let my father rest now? } \\
\text { What is this medication supposed to do for } \\
\text { him? } \\
\text { So you ran the tests, we know he had a stroke, } \\
\text { hes on tPA for the clot and is receiving IV } \\
\text { fluids- what else can you do for him? } \\
\text { Patient: } \\
\text { I don't feel good. } \\
\text { I just pee what did you do with it nurse? }\end{array}$ \\
\hline
\end{tabular}




\begin{tabular}{|c|c|c|}
\hline & $\begin{array}{l}\text { Patient: } \\
\text { What is that you are injecting? Rose can you do something! } \\
\text { Daughter: } \\
\text { Fine, I'll get the urinal for you dad because these people } \\
\text { aren't helping you. } \\
\text { Patient: } \\
\text { Hunny they are going to make me pee on myself. } \\
\text { Can you tell them to help me pee omg what does it take for } \\
\text { me to pee } \\
\text { I don't want nothing done on me I need to pee. }\end{array}$ & $\begin{array}{l}\text { Wife: } \\
\text { "Babe what is your pain level? } \\
\text { "In my country we do natural herbs for pain" }\end{array}$ \\
\hline $\begin{array}{l}\text { Patient teaching regarding } \\
\text { stroke risk factors and pre- } \\
\text { vention }\end{array}$ & $\begin{array}{l}\text { Nurse \#1 } \\
\text { Identify risk factors that predispose an individual to suffer a } \\
\text { stroke. } \\
\text { "Your father has high cholesterol and blood pressure." "Yes } \\
\text { smoking also contributes to a stroke." Also he is obese. } \\
\text { Nurse \#2 } \\
\text { Provide emotional support to the wife and daughter } \\
\text { Daughter: } \\
\text { Yes and my father smokes } \\
\text { Patient: } \\
\text { Thank u rose your finally helping. } \\
\text { Daughter: } \\
\text { ur welcome dad } \\
\text { Can someone please tell me WHY my dad had a stroke???? } \\
\text { PLEASE } \\
\text { I'm going to get my dad out of here you people are useless } \\
\text { Patient: } \\
\text { Why cant u explain nurse!? You're the nurse } \\
\text { You should know } \\
\text { I am so confused. } \\
\text { Patient to wife: } \\
\text { Susan I'm not dying } \\
\text { Daughter: } \\
\text { How do you know dad you could be dying but this so called } \\
\text { doctor doesn't know anything } \\
\text { Ok I know that and he also smokes is that bad too? }\end{array}$ & $\begin{array}{l}\text { Nurse } \\
\text { "He is predisposed for having a stroke because } \\
\text { he is obese, smokes, as well as his ethnicity." } \\
\text { "He can stop smoking and eat healthier." } \\
\text { Daughter: } \\
\text { Doctor what's happening to my father? } \\
\text { So how are we supposed to help him with all } \\
\text { those risk factors? } \\
\text { Patient: } \\
\text { "is the results of the tests in? I want to go } \\
\text { home." } \\
\text { Wife: } \\
\text { "He is admitted, right?" }\end{array}$ \\
\hline
\end{tabular}

Figure 8. Patient scenario flow chart.

(The case scenario: Samuel Dexter is a 52-year-old African-American man who is both a husband and father. He is moderately obese (BMI of 32), and has smoked two packs of cigarettes a day for the past 38 years. He awakes one morning with weakness on his right side. He is a bit confused, sees double, and his speech is slurred. When he attempts to walk to the bathroom, he stumbles a few times and falls once. His wife suspects that he has suffered a stroke and calls 911. Emergency personnel arrive within minutes of her call and transport Samuel to the ER of the nearest hospital.)

\section{LIMITATIONS}

The case scenario itself may have stifled some student's responses and creativity- they may have perceived that they needed to closely follow the script. It may be preferable to have a more open-ended scenario that presents a patient, relevant symptoms and diagnostic test results, but allows the participants to freely determine the entire assessment, admission, and nursing intervention process.

Unfamiliarity with the virtual environment could be another limitation. Some students readily engaged while some others seemed hesitant initially. This may be a reflection of their age or previous experience with technology and/or gaming modalities.

It is difficult to determine the impact of prior knowledge, clinical experiences, or personal healthcare system encounters on responses. The pretest scores ranged from 7-14 with a mean of 9. An analysis to determine cognitive gains among the groups from pre-test to posttest revealed no statistically significant differences. The students were all in the same class and this was their first exposure to CVAs in the curriculum; however some students are employed in healthcare or may have family members who suffered a stroke. Additionally some students may have completed assigned readings for the unit.

Although the prior knowledge from both groups showed no significant difference via multiple-choice based questions, other forms of pretest should be considered for a more complete picture of students' prior knowledge. The content of the pre- post-test questions may not have effectively measured cognitive learning. Short answer questions may better reflect cognitive learning in such scenarios.

\section{CONCLUSIONS AND Future DiRECTIONS}

This study focuses on social behaviors in a virtual context and identifies strengths and weaknesses of such an approach to be used in a classroom. Our study indicates that the Virtual Group participated more both quantitatively and qualitatively in the virtual field trip. Although the Text Group did better at knowledge sharing, they engaged much less on all the other higher-level aspects of social interactions, such as meaning negotiation and knowledge construction. We will investigate further on the implications of this study towards promoting social learning. 


\section{REFERENCES}

[1] Dawley, Lisa (2009) Social Network Knowledge Construction: Emerging Virtual World pedagogy. On The Horizon 17(2), 109121 http://dx.doi.org/10.1108/10748120910965494

[2] Tytler, Russell (2003) A window for a purpose: developing a framework for describing effective science teaching and learning, Research in science education, vol. 33, no. 3, pp. 273-298. http://dx.doi.org/10.1023/A:1025423704068

[3] Dede, C., Salzman, M., \& Loftin, R. B. (1996). The development of a virtual world for learning Newtonian mechnics. In P. Brusilovsky, P. Kommers, \& N. Streitz (Eds.), Multimedia, hypermedia, and virtual reality (pp. 87-106). Berlin: Springerhttp://dx.doi.org/10.1007/3-540-61282-3_10

[4] Dede, C. (1995). The evolution of constructivist learning environments: Immersion in distributed virtual worlds. Educational Technology, 35 (5), 46-52.

[5] Hew, K. \& Cheung, W (2008). Use of three-dimensional (3-D) immersive virtual worlds in K-12 and higher education settings: A review of the research. British Journal of Educational Technology, Vol. 41, No. 1, pp. 33-55. http://dx.doi.org/10.1111/j.14678535.2008.00900.x

[6] Oliver, M., \& Carr, D. (2009). Learning in virtual worlds: Using communities of practice to explain how people learn from play. British Journal of Educational Technology, 40(3), 444-457.

[7] Glenberg, A.M. (1997) What memory is for. Behavioral and Brain Sciences, 20, 1-55.

[8] Barsalou, L.W., (2008) Grounded cognition. Annual Review of Psychology, 59(1), pp.617-645.

[9] Black, J.B., Segal, A., Vitale, J. and Fadjo, C. (2012). Embodied cognition and learning environment design. In D. Jonassen and S. Lamb (Eds.) Theoretical foundations of student-centered learning environments. New York: Routledge http://dx.doi.org/10.1111/ j.1467-8535.2009.00948.x

[10] Shulman, L. S., \& Hutchins, P. (2004). Teaching as community property: Essays on higher education. San Francisco, CA: JosseyBass.

[11] Abt, C. (1970). Serious Games. New York: The Viking Press.

[12] Prensky, M. (2005). What can you learn from a cell phone? Almost anything! Innovate, 1(5),

[13] Gee, J. P. (2007). What Videogames Have to Teach Us about Learning and Literacy (. 2nd Ed.). New York: Palgrave MacMillan.

[14] Aldrich, C. (2004). Simulations and the future of learning. San Francisco, CA: Pfeiffer.

[15] Quinn, C. N. and Conner. M. L. (2005). Engaging learning: Designing e-learning simulation games. San Francisco, Pfeiffer.

[16] Squire, K. (2004) Replaying History: Learning World History through playing Civilization III. Doctoral Dissertation, Indiana University, Bloomington, Indiana

[17] Pursel, B. and K. Bailey (2008). Establishing virtual learning worlds. Virtual reality: Concepts and Applications. P. Rao and S. Zodgekar, Icfai University Press.

[18] Steinkuehler, C. (2008). "Massively multiplayer online games as an educational technology: An outline for research." Educational Technology 48(1): 10-21.

[19] Aldrich, C. (2005). Learning by doing: A comprehensive guide to simulations, computer games and pedagogy in e-learning and other educational experiences, John Wily and Sons.

[20] DeMarco, M., E. Lesser, et al. (2007, June 12, 2007). "Leadership in a distributed world: Lessons from online gaming." Retrieved August 2, 2008.

[21] Garner, L. C., \& Gallo, M. A. (2005). Field trips and Their Effect on Student Achievement and Attitudes: A Comparison of Physical versus Virtual Field trips to the Indian River Lagoon. Journal Of College Science Teaching, 34(5), 14-17.

[22] Puhek, M., Perše, M., \& Šorgo, A. (2012). Comparison Between A Real Field trip And A Virtual Field trip In A Nature Preserve: Knowledge Gained In Biology And Ecology. Journal Of Baltic Science Education, 11(2), 164-174.

[23] Oliver, M., \& Carr, D. (2009). Learning in virtual worlds: Using communities of practice to explain how people learn from play.
British Journal of Educational Technology, 40(3), 444-457. http://dx.doi.org/10.1111/j.1467-8535.2009.00948.x

[24] Stokowski, L. A., (2013) Digital Revolution: Games, Simulations, and Virtual Worlds in Nursing Education. Medscape. WebMD, LLC

[25] Paige, J. B., \& Daley, B. J. (2009). Situated cognition: A learning framework to support and guide high-fidelity simulation. Clinical Simulation in Nursing, 5(3), e97-e103 http://dx.doi.org/10.1016/ j.ecns.2009.03.120

[26] Galloway, S. J., (2009) Simulation Techniques to Bridge the Gap Between Novice and Competent Healthcare Professionals OJIN: The Online Journal of Issues in Nursing, 14(2).

[27] Wotton, K., Davis, J., Button, D., \& Kelton, M. (2010). Third Year Undergraduate Nursing Students' Perceptions of High Fidelity Simulation. Journal of Nursing Education, 49(11) 632639http://dx.doi.org/10.3928/01484834-20100831-01

[28] Oishi, M, Fukuda, M., Ishida, G., Saito, A., Hiraishi, T. and Fujii, Y. (2011) Presurgical Simulation With Advanced 3-Dimensional Multifusion Volumetric Imaging in Patients With Skull Base Tumors. Neurosurgery 68, ons188-ons 199 http://dx.doi.org/10.1227/ NEU.0b013e318207b3ad

[29] Malone, H., Syed, O., Downes, M. D’Ambrosio, A., Quest, D. and Kaiser, M. (2010) Simulation in Neurosurgery: A Review of Computer-Based Simulation Environments and Their Surgical Applications. Neurosurgery 67: 4, 1105-1116 Online publication date: 1-Oct-2010.

[30] Low, D. Lee, C., Dip, L., Ng, W., Ang, B. and Ng (2010) Augmented reality neurosurgical planning and navigation for surgical excision of parasagittal, falcine and convexity meningiomas. British Journal of Neurosurgery 24:1, 69-74 Online publication date: 1-Feb-2010.

[31] Walker, J., Perkins, E. and Harkey, L. (2009) A Novel Simulation Model For Minimally Invasive Spine Surgery Neurosurgery 65,188-195

[32] Kallonis, P and Sampson, D (2010) Implementing a 3D Virtual Classroom Simulation for Teachers' Continuing Professional Development; in S. L. Wong et al (2010) Proceedings of the 18th international conference on computers in education Malaysia.

[33] Leung, G., Yucel, G. and Duffy, V. (2010) The effects of virtual industrial training on mental workload during task performance. Human Factors and Ergonomics in Manufacturing \& Service Industries 20: 6, 567-578. http://dx.doi.org/10.1002/hfm.20198

[34] Bai, X., Duncan, R. O., Horowitz, B., Glodstein, S., Graffeo, J., Lavin, J.. "The Added Value of 3D Simulations in Healthcare Education." International Journal of Nursing Education. 4(2) 2012: $67-72$.

[35] Bai, X., Lavin, J, Duncan, R. O.. "Are we there yet? Lessons learned through promoting 3D learning in higher education." The International Journal of Learning. 18(6) 2012: 1-14.

[36] Vaishnavi, V. and Kuechler, W. (2004/5). Design Research in Information Systems Retrieved in January, 2010 from http://www.isworld.org/Researchdesign/drisISworld.htm

[37] Brown, A. L. (1992). Design experiments: Theoretical and methodological challenges in creating complex interventions. Journal of the Learning Sciences, 2, 141-178. http://dx.doi.org/10.1207/ s15327809j1s0202_2

[38] Collins, A., Joseph, D., Katerine and Bielaczyc K. (2004). Design research: theoretical methodological issues. Journal of the Learning Sciences, Vol. 13, No. 1: pages 43-76. http://dx.doi.org/10.1207/s15327809jls1301 2

[39] Bricken, M. \& Byrnes, C. M. (1993). Summer students in virtual reality: a pilot study on educational applications of virtual reality technology. In A. Wexelblat (Ed.), Virtual reality: applications and explorations (pp. 199-217). Boston, MA: Academic. http://dx.doi.org/10.1016/B978-0-12-745045-2.50019-2

[40] Winn, W. (1997). The impact of three-dimensional immersive virtual environments on modern pedagogy. HITL Report R-97-15. Retrieve March 8, 2012, from http://www.hitl.washington.edu/publications/r-97-15/

[41] Gunawardena, C., Lowe, C., \& Anderson, T. (1997). Analysis of global online debate and the development of an interaction analysis model for examining social construction of knowledge in computer conferencing. Journal of Educational Computing Research, 
17(4), 397-431. http://dx.doi.org/10.2190/7MQV-X9UJ-C7Q3NRAG

[42] Hou, H. (2012). Analyzing The Learning Process Of An Online Role-Playing Discussion Activity. Educational Technology \& Society. $15.1, \mathrm{p} 211$

[43] Hou, H. T., Chang, K. E., \& Sung, Y. T. (2007). An analysis of peer assessment online discussions within a course that uses project-based learning. Interactive Learning Environments, 15(3), 237-251. http://dx.doi.org/10.1080/10494820701206974

[44] Hou, H. T., Chang, K. E., \& Sung, Y. T. (2009). Using blogs as a professional development tool for teachers: Analysis of interaction behavioral patterns. Interactive Learning Environments, 17(4), 325-340. http://dx.doi.org/10.1080/10494820903195215

[45] Jeong, A. C. (2003). The sequential analysis of group interaction and critical thinking in online threaded discussions. American Journal of Distance Education, 17(1), 25-43. http://dx.doi.org/10.1207/S15389286AJDE1701 3

[46] Sing, C. C., \& Khine, M. S. (2006). An Analysis of Interaction and Participation Patterns in Online Community. Educational Technology \& Society, 9 (1), 250-261.

[47] Schellens, T., \& Valcke, M. (2005). Collaborative learning in asynchronous discussion groups: What about the impact on cognitive processing? Computers in Human Behavior, 21 (6), 957-976. http://dx.doi.org/10.1016/j.chb.2004.02.025
[48] Zhao, Y., \& Rop, S. (2001). A critical review of the literature on electronic networks as reflective discourse communities for inservice teachers. Education and Information Technologies, 6 (2), 81-94. http://dx.doi.org/10.1023/A:1012363715212

\section{ACKNOWLEDGMENT}

Support for this project has been provided by CUNY's Workforce Development Initiative and Incentive Grant programs. We want to thank all involved in this project.

\section{AUTHORS}

Xin Bai is an Assistant Professor of Educational Technology in the Department of Teacher Education at York College, City University of New York, 94-20 Guy R. Brewer Blvd. \#AC-1E17, Jamaica NY 11451 (email: xbai@york.cuny.edu)

Joanne Lavin is the Associate Director of Nursing at CUNY School of Professional Studies 101 West 31 Street New York, NY 10001 (e-mail: Joanne.lavin@cuny.edu)

Submitted, April 17, 2014. Published as resubmitted by the authors on May 10, 2014. 